\title{
ASAS PEMERIKSAAN PENGADILAN TERBUKA UNTUK UMUM DALAM TINDAK PIDANA PERJUDIAN SEBAGAI KEJAHATAN KESUSILAAN \\ (Studi Kasus Di Pengadilan Negeri Purbalingga) Ageng Priambodo Pamungkas \\ (Hakim Pengadilan Negeri Purbalingga,
}

E-mail: ageng priambodo@yahoo.com/081352330376)

\begin{abstract}
Article 153 paragraph (3) of the Criminal Procedural Code determines for the purpose of examination, the chair of the judicial session to open hearings and declare open to the public except in matters concerning the morality or the offense of children. In practice, the examination of gambling matters as a crime against morality, by the Judicial Council of PN Purbalingga, was made public. The research method uses normative juridical method. Data sources in the form of secondary data are supported with primary data. The first conclusion, the consideration of the Judicial Assembly of PN Purbalingga states that the trial of criminal acts of gambling is open to the public, due to the practice in practice. Gambling crime is a crime of morality in a broad sense. There are no statutory rules governing the procedure of gambling criminal proceedings. The second conclusion, there are two understandings of the meaning of morality, namely morality in the narrowed meaning of which is related to sexual and moral in a broadly unlimited sexual sense. Gambling is included in morality in an infinite sense of sexual activity.

Keyword: Gambling, decency, open to the public
\end{abstract}

\section{Abstrak}

Pasal 153 ayat (3) KUHAP menentukan untuk keperluan pemeriksaan, hakim ketua sidang membuka sidang dan menyatakan terbuka untuk umum kecuali dalam perkara mengenai kesusilaan atau terdakwanya anak-anak. Dalam prakteknya, pemeriksaan perkara perjudian sebagai suatu kejahatan terhadap kesusilaan, oleh Majelis Hakim PN Purbalingga, dilakukan terbuka untuk umum. Metode penelitian menggunakan metode yuridis normatif. Sumber data berupa data sekunder didukung dengan data primer. Simpulan pertama, pertimbangan Majelis Hakim PN Purbalingga menyatakan persidangan tindak pidana perjudian terbuka untuk umum, karena kebiasaan dalam praktek. Tindak pidana perjudian merupakan kejahatan kesusilaan dalam arti luas. Tidak ada aturan perundang-undangan yang mengatur secara khusus terhadap tata cara pemeriksaan persidangan tindak pidana perjudian. Simpulan kedua, ada dua pemahaman terhadap makna kesusilaan, yaitu kesusilaan dalam pengertian yang disempitkan yaitu yang berhubungan dengan seksual dan kesusilaan dalam arti luas yang tidak terbatas pada seksual. Judi termasuk dalam perkara kesusilaan dalam arti luas yang tidak terbatas pada seksual.

Kata Kunci : judi, kesusilaan, terbuka untuk umum

\section{Pendahuluan}

Semua sidang pemeriksaan perkara di Pengadilan, pada asasnya harus dilaksanakan dalam sidang yang terbuka untuk umum. Salah satu tujuannya adalah untuk menghindari terjadinya penyimpangan dalam proses pemeriksaan. Terbukanya sidang untuk umum ini merupakan salah satu bentuk kontrol.

Asas pemeriksaan pengadilan terbuka untuk umum ini diatur dalam Pasal 13 ayat (1) Undang-undang Republik Indonesia Nomor 48 Tahun 2009 tentang Kekuasaan Kehakiman yang berbunyi :

"Semua sidang pemeriksaan pengadilan adalah terbuka untuk 
umum, kecuali undang-undang menentukan lain."

Dalam hukum acara pidana, asas pemeriksaan pengadilan terbuka untuk umum diatur dalam Pasal 153 Kitab Undang-undang Hukum Acara Pidana / KUHAP yang berbunyi:

ayat (3)

"Untuk keperluan pemeriksaan, hakim ketua sidang membuka sidang dan menyatakan terbuka untuk umum kecuali dalam perkara mengenai kesusilaan atau terdakwanya anak-anak."

ayat (4)

"Tidak dipenuhinya ketentuan dalam ayat 2 dan 3 mengakibatkan batalnya putusan demi hukum."

Berdasarkan ketentuan di atas, maka Hakim wajib menyatakan sidang terbuka untuk umum pada saat pemeriksaan perkara kecuali dalam perkara kesusilaan atau terdakwanya anak-anak. Meskipun pemeriksaan dalam perkara susila atau terdakwanya masih anak-anak dilakukan tertutup untuk umum, tetapi dalam pembacaan putusan, sidang harus dinyatakan terbuka untuk umum. Apabila hakim pengadilan dalam memeriksa suatu perkara melanggar ketentuan-ketentuan tersebut, maka putusan hakim pengadilan tersebut batal demi hukum. Demikian juga, apabila pemeriksaan terdakwa dalam perkara mengenai kesusilaan atau Terdakwanya masih anak-anak dilakukan dalam pemeriksaan terbuka untuk umum, maka putusan hakim pengadilan negeri tersebut batal demi hukum.
Untuk menentukan apakah seorang terdakwa termasuk kriteria terdakwa anak atau bukan, Undangundang Nomor 11 Tahun 2012 Tentang Sistem Peradilan Pidana Anak telah memberikan batasan yang jelas. Untuk menentukan suatu perkara termasuk kriteria perkara mengenai kesusilaan atau bukan adalah dengan melihat ketentuan yang mengatur tentang kesusilaan.

Berdasarkan letak pengaturannya dalam hukum positif kita, kejahatan terhadap kesusilaan dapat di golongkan menjadi dua, yaitu kejahatan terhadap kesusilaan yang diatur di dalam Kitab Undang-undang Hukum Pidana / KUHP dan kejahatan terhadap kesusilaan yang diatur di luar KUHP. Mengenai kejahatan terhadap kesusilaan yang diatur di dalam KUHP yaitu kejahatankejahatan sebagaimana di sebutkan dalam Bab XIV tentang kejahatan terhadap kesusilaan, sedangkan kejahatan terhadap kesusilaan yang diatur di luar KUHP diatur dalam beberapa peraturan perundangundangan, diantaranya adalah Pasal 81 dan Pasal 82 Undang-undang Nomor 35 Tahun 2014 tentang Perubahan Atas Undang-Undang Nomor 23 Tahun 2002 Tentang Perlindungan Anak.

Mendengar istilah kejahatan terhadap kesusilaan, mengingatkan kita pada delik-delik seksual seperti persetubuhan, pencabulan, perzinahan dan pelacuran yang pada pokoknya berhubungan dengan nafsu birahi/ kelamin atau sex-related. Hal ini 
mempunyai nilai sosiologis karena telah diterima oleh kalangan luas dari masyarakat, terlepas dari persoalan apakah ini yang dikehendaki oleh hukum pidana positif kita maupun dalam yurisprudensi hukum pidana kita.

Namun demikian, Kejahatankejahatan terhadap kesusilaan yang diatur dalam Bab XIV KUHP, ternyata tidak semuanya berkaitan dengan nafsu birahi/ kelamin atau kejahatan yang berkaitan dengan seksual semata. Dari 25 (dua puluh lima) Pasal yang diatur dalam Bab XIV KUHP tentang Kejahatan terhadap Kesusilaan, ada 2 (dua) Pasal yang mengatur tentang perjudian yaitu Pasal 303 dan 303 Bis.

Pasal 153 ayat (3) KUHAP berikut penjelasannya tidak memberikan definisi maupun membedakan kesusilaan menjadi dua yaitu kesusilaan yang berhubungan dengan nafsu birahi dan kesusilaan yang tidak berhubungan dengan nafsu birahi. Oleh karenanya, dengan mendasarkan pada ketentuan Pasal 153 ayat (3) KUHAP tersebut, maka terhadap seluruh pasal dalam Bab XIV KUHP tentang kejahatan terhadap kesusilaan, proses pemeriksaan persidangannya harus dilakukan tertutup untuk umum.

Pada tahun 2015, Pengadilan Negeri Purbalingga telah menerima, memeriksa dan memutus 24 (dua puluh empat) perkara judi sebagaimana diatur dan diancam pidana dalam pasal 303 dan 303 Bis KUHP. Dari 24 (dua puluh empat) perkara judi yang telah diputus tersebut, proses pemeriksaan persidangannya dilakukan secara terbuka untuk umum.

\section{Rumusan Masalah}

Berdasarkan latar belakang di atas, maka rumusan masalah dalam tulisan ini adalah:

1. Apa yang menjadi pertimbangan hukum majelis hakim Pengadilan Negeri Purbalingga sehingga menyatakan sidang pemeriksaan pengadilan terbuka untuk umum dalam tindak pidana perjudian menurut Pasal 303 dan 303 bis KUHP pada kurun waktu tahun 2015?

2. Apakah penerapan asas pemeriksaan pengadilan terbuka untuk umum dalam tindak pidana perjudian menurut Pasal 303 dan 303 bis KUHP telah sesuai dengan ketentuan hukum acara pidana?

\section{Metode Penelitian}

Metode penelitian yang dipergunakan adalah yuridis normatif. Sumber data berupa data sekunder didukung dengan data primer. Analisis data yang akan dipergunakan dalam penelitian ini adalah metode analisis data normatif kualitatif. Penelitian dilakukan di Pengadilan Negeri Purbalingga.

\section{Pembahasan}

1. Pertimbangan hukum majelis hakim Pengadilan Negeri Purbalingga menyatakan sidang pemeriksaan pengadilan terbuka untuk umum dalam tindak pidana perjudian menurut Pasal 303 dan 303 bis KUHP. 
Puncak dari proses mengadili yang dilakukan oleh Pengadilan adalah dengan dibacakannya putusan. Mengenai hal-hal apa saja yang harus dimuat dalam suatu putusan hakim dalam mengadili perkara pidana, telah ditentukan dalam Pasal 197 KUHAP.

Suatu putusan Hakim akan memuat memuat segala pertimbangan dalam rangkaian proses mengadili suatu perkara. Namun demikian, berdasarkan Pasal 197 KUHAP tersebut, mengenai terbuka atau tertutupnya suatu pemeriksaan pengadilan beserta pertimbangannya, tidak ada kewajiban bagi Majelis Hakim untuk memuatnya di dalam putusan. Untuk dapat mengetahui suatu pemeriksaan yang sudah dilakukan di Pengadilan apakah dilakukan secara terbuka atau tertutup, maka dapat melihat kepada risalah/ berita acara persidangan.

Berdasarkan data sekunder berupa berita acara persidangan dalam tindak pidana perjudian yang disidangkan di PN Purbalingga pada tahun 2015, PN Purbalingga telah menerima dan memutus sebanyak 24 (dua puluh empat) tindak pidana perjudian .

Berdasarkan berita acara persidangan tindak pidana perjudian tersebut, seluruh tindak pidana perjudian yang diperiksa oleh Pengadilan Negeri Purbalingga, persidangan dilakukan secara terbuka untuk umum. Hakim Ketua menyatakan sidang terbuka untuk umum, namun di dalam putusan maupun berita acara persidangan, tidak disertai dengan pertimbangan mengapa sidang dilakukan secara terbuka untuk umum.

Dalam hukum pidana, asas pemeriksaan pengadilan terbuka untuk umum diatur dalam Pasal 153 KUHAP. Berdasarkan ketentuan tersebut, maka Hakim harus menyatakan sidang tertutup untuk umum pada saat pemeriksaan perkara mengenai kesusilaan atau Terdakwanya masih anak-anak. Apabila hakim dalam memeriksa suatu perkara melanggar ketentuan terbuka untuk umum kecuali perkara kesusilaan atau terdakwanya masih anak-anak, maka putusan hakim pengadilan tersebut batal demi hukum. Demikian juga, jika pemeriksaan terdakwa dalam perkara mengenai kesusilaan atau terdakwanya masih anak-anak dilakukan dalam pemeriksaan terbuka untuk umum, maka putusan hakim pengadilan negeri tersebut batal demi hukum. Meskipun pemeriksaan dalam perkara kesusilaan atau terdakwanya masih anak-anak dilakukan tertutup untuk umum, tetapi dalam pembacaan putusan, sidang harus dinyatakan terbuka untuk umum.

$$
\text { Menurut Tolib Effendi, }{ }^{1}
$$
Keterbukaan perlakuan oleh aparat penegak hukum kepada tersangka/ terdakwa, tidak dirahasiakan segala sesuatu yang menyangkut pemeriksaan terhadap tersangka/terdakwa. Semua

Tolib Effendi, 2014, Dasar-dasar hukum acara pidana.: perkembangan dan pembaharuannya di Indonesia, Setara press, Malang, hlm. 14. 
hasil pemeriksaan yang menyangkut diri tersangka/terdakwa tentang kesalahan yang disangkakan kepada tersangka sejak tingkat penyidikan harus disampaikan secara terbuka sampai dengan tingkat pemeriksaan di persidangan.

Secara formil asas pemeriksaan pengadilan terbuka untuk umum, membuka kesempatan "social control" yang bertujuan agar masyarakat bisa mengetahui secara langsung terhadap proses hukum sehingga dapat memberikan kontrol demi terwujudnya keadilan. Pengertian asas terbuka untuk umum ini meliputi proses pemeriksaan Pengadilan hingga putusan hakim. Mengenai hal tersebut, Fence $M$. Wantu ${ }^{2}$ berpendapat :

"Pengertian asas ini dapat berarti
bahwa siapapun boleh hadir,
mendengar dan menyaksikan
jalannya pemeriksaan perkara di
pengadilan. Asas ini merupakan
pengawasan atau kontrol sosial
terhadap jalannya peradilan,
sekalipun tidak merupakan kontrol
langsung terhadap jalannya
persidangan, yang akan lebih
menjamin objektifitas pemeriksaan
yang fair sampai pada putusan yang
adil kepada masyarakat. Selain itu
asas ini untuk menjamin
pelaksanaan peradilan yang tidak
memihak dan adil, serta melindungi
hak asasi siapapun yang beracara di
pengadilan." Prinsip keterbukaan sidang pengadilan tersebut berarti bahwa setiap orang diperbolehkan hadir dan mendengarkan pemeriksaan di persidangan. Tujuan daripada asas ini

\footnotetext{
${ }^{2}$ Fence M.Wantu, loc.cit.
}

tidak lain untuk memberikan perlindungan hak-hak asasi manusia dalam bidang peradilan serta untuk lebih menjamin objektivitas peradilan dengan mempertanggungjawabkan

pemeriksaan yang fair, tidak memihak, serta putusan yang adil kepada masyarakat.

Bahwa sidang pemeriksaan pengadilan tertutup untuk umum, dalam prakteknya dilakukan terhadap perkara anak sebagai bentuk perlindungan anak dari eksploitasi. Selain dalam perkara anak, sidang pemeriksaan pengadilan juga dilakukan tertutup untuk umum dalam perkara kesusilaan seperti zina, persetubuhan dan pencabulan. Hal ini dikarenakan dalam perkara zina, persetubuhan dan pencabulan ada halhal yang tidak pantas diperdengarkan kepada publik.

Tertutupnya sidang untuk umum dalam perkara zina, persetubuhan dan pencabulan dimaksudkan untuk melindungi dan menjaga psikologi saksi korban. Perlindungan terhadap saksi korban yaitu agar saksi korban dalam memaparkan peristiwa yang dialaminya tanpa harus merasa malu membuka aibnya kembali di depan umum. Saksi korban tidak akan merasa dipermalukan di depan umum karena membuka aib yang menimpanya. Selain itu, dengan terbukanya sidang untuk umum dalam perkara zina, persetubuhan dan pencabulan, dikhawatirkan akan membatasi saksi korban dan terdakwa dalam memberikan keterangan karena adanya perasaan malu, sehingga 
kebenaran materill yang hendak dicapai dalam pembuktian perkara pidana tidak akan diperoleh. Mengenai hal ini, Wirjono Prodjodikoro ${ }^{3}$ memberikan pendapatnya:

"Ada kalanya dirasakan perlu untuk melarang khalayak ramai menyaksikan pemeriksaan perkara pidana oleh hakim. Biasanya keperluan ini dirasakan dalam perkara-perkara pidana mengenai hal kesusilaan, misalnya hal memperkosa seorang gadis untuk bersetubuh. Dalam hal ini, kalau khalayak ramai menyaksikan pemeriksaan perkara ada banyak kemungkinan bahwa terdakwa dan saksi-saksi yang bersangkutan sangat malu untuk memajukan keterangan yang sebenarnya, hal mana akan menyulitkan pemeriksaan perkara sedemikian rupa, sehingga hakim tidak dapat mengambil suatu putusan yang tepat."

Hal yang sama disampaikan juga oleh Muhammad Taufik Makaro ${ }^{4}$ bahwa pengecualian terhadap kesusilaan karena kesusilaan dianggap masalahnya sangat pribadi sekali. Tidak patut untuk mengungkapkan dan memaparkannya secara terbuka di muka umum.

Untuk mengetahui apa yang menjadi pertimbangan hukum majelis hakim Pengadilan Negeri Purbalingga menyatakan sidang pemeriksaan pengadilan terbuka untuk umum dalam tindak pidana perjudian menurut Pasal 303 dan 303 bis KUHP, hal tersebut dapat diperoleh dari data primer berupa hasil wawancara dengan Majelis Hakim pada Pengadilan Negeri Purbalingga.

Wirjono Prodjodikoro, loc.cit.

Muhammad Taufik Makaro, Suhasril, Loc. Cit.
Berdasarkan data primer, para Narasumber berpendapat bahwa tindak pidana perjudian sebagaimana diatur dalam Pasal 303 dan 303 bis KUHP termasuk kejahatan kesusilaan, kecuali Narasumber Arief Yudiarto yang berpendapat bahwa tindak pidana perjudian sebagaimana diatur dalam Pasal 303 dan 303 bis KUHP bukan termasuk kejahatan kesusilaan. Namun, meskipun termasuk kejahatan kesusilaan, pemeriksaan persidangan dilakukan secara terbuka untuk umum dengan alasan bahwa hal tersebut merupakan suatu kebiasaan dalam praktek pengadilan. Alasan yang lain adalah karena judi termasuk kejahatan kesusilaan dalam pengertian yang luas, tidak berhubungan dengan seksual sehingga pemeriksaan persidangannya harus terbuka untuk umum. Selain alasan-alasan tersebut, tidak ada aturan perundang-undangan yang mengatur secara khusus terhadap tata cara pemeriksaan persidangan tindak pidana perjudian sebagai kejahatan kesusilaan harus tertutup untuk umum.

Berdasarkan pembahasan di atas, menurut penulis apabila Majelis Hakim Pengadilan Negeri Purbalingga berpendapat bahwa tindak pidana perjudian merupakan kejahatan kesusilaan, maka sesuai dengan ketentuan Pasal 153 ayat (3) KUHAP, seharusnya pemeriksaan persidangan dilakukan secara tertutup untuk umum. Majelis Hakim Pengadilan Negeri Purbalingga berpendapat bahwa tindak pidana perjudian sebagai kejahatan 
kesusilaan namun pemeriksaan persidangannya dilakukan secara terbuka untuk umum mendasarkan kepada pertimbangan bahwa judi termasuk kejahatan kesusilaan dalam pengertian yang luas, tidak berhubungan dengan seksual sehingga pemeriksaan persidangannya harus terbuka untuk umum. Hal tersebut sudah menjadi kebiasaan di dalam praktik peradilan dan selama ini tidak ada aturan perundang-undangan yang mengatur secara khusus mengenai terbuka atau tertutupnya pemeriksaan persidangan dalam tindak pidana perjudian.

2. Penerapan asas pemeriksaan pengadilan terbuka untuk umum dalam tindak pidana perjudian menurut Pasal 303 dan 303 bis KUHP apakah sesuai dengan ketentuan hukum acara pidana.

Berdasarkan data sekunder berupa berita acara persidangan dalam perkara perjudian yang disidangkan di Pengadilan Negeri Purbalingga pada tahun 2015, Pengadilan Negeri Purbalingga telah menerima dan memutus sebanyak 24 (dua puluh empat) tindak pidana perjudian. Seluruh tindak pidana perjudian yang diperiksa oleh Pengadilan Negeri Purbalingga tersebut, pemeriksaannya dilakukan secara terbuka untuk umum. Hakim Ketua menyatakan sidang terbuka untuk umum, namun di dalam putusan maupun berita acara persidangan, tidak disertai dengan pertimbangan mengapa sidang dilakukan secara terbuka untuk umum.

Sebagaimana telah diuraikan dalam pembahasan permasalahan pertama, Majelis Hakim Pengadilan Negeri Purbalingga berpendapat bahwa tindak pidana perjudian sebagai kejahatan kesusilaan namun pemeriksaan persidangannya dilakukan secara terbuka untuk umum mendasarkan kepada pertimbangan bahwa judi termasuk kejahatan kesusilaan dalam pengertian yang luas, tidak berhubungan dengan seksual sehingga pemeriksaan persidangannya harus terbuka untuk umum. Hal tersebut sudah menjadi kebiasaan di dalam praktik peradilan dan selama ini tidak ada aturan perundang-undangan yang mengatur secara khusus mengenai terbuka atau tertutupnya pemeriksaan persidangan dalam tindak pidana perjudian.

Apabila Majelis Hakim Pengadilan Negeri Purbalingga berpendapat bahwa tindak pidana perjudian termasuk dalam kejahatan kesusilaan, maka sesuai ketentuan Pasal 153 ayat (3) Kitab Undang-undang Hukum Acara Pidana, pemeriksaan persidangannya harus dinyatakan tertutup untuk umum. Dalam prakteknya, Majelis Hakim Pengadilan Negeri Purbalingga menyatakan sidang terbuka untuk umum. Hal tersebut tentu menimbulkan permasalahan apakah penerapan asas pemeriksaan persidangan terbuka untuk umum dalam perkara perjudian sebagai kejahatan 
kesusilaan sesuai dengan Hukum Acara

Pidana?

$$
\text { Guna membahas dan }
$$

menganalisa permasalahan tersebut,

Penulis akan menggunakan teori penemuan hukum. Pembahasan akan dilakukan dengan menggunakan metode-metode yang disediakan dalam teori Penemuan Hukum.

Seperti diketahui bahwa hukum atau peraturan perundang-undangan itu tidak lengkap dan tidak selalu jelas dan tidak mungkin lengkap selengkaplengkapnya atau jelas sejelas-jelasnya. Oleh karena itu perlu dilengkapi atau dijelaskan dengan mencari atau menemukan hukumnya.

Mengenai apa yang dimaksud dengan penemuan hukum, Sudikno ${ }^{5}$, memberikan pendapatnya :

"Penemuan hukum pada dasarnya merupakan kegiatan praktek hukum (hakim, pembentuk undangundang, dan sebagainya). Akan tetapi penemuan hukum tidak dapat dipisahkan dari ilmu (teori) hukum. Kalaupun secara historis teoritis praktek hukum itu lahirnya lebih dahulu dari ilmu hukum, tetapi dalam perkembangannya praktek hukum memerlukan landasan teoritis dari ilmu hukum, sebaliknya ilmu hukum memerlukan materialnya dari praktek hukum. Jadi dalam prakteknya, praktek hukum dan ilmu hukum itu saling memerlukan satu sama lain".

Lebih lanjut dikemukakan oleh Sudikno $^{6}$ bahwa Undang-undang sebagaimana norma pada umumnya, berfungsi untuk melindungi kepentingan

5 Sudikno Mertokusumo, Penemuan Hukum, Op. cit, hlm. 1.

6 Sudikno Mertokusumo, Mengenal Hukum,Op. cit., hlm. 168. manusia, sehingga harus dilaksanakan atau ditegakkan. Undang-undang harus diketahui oleh umum, tersebar luas dan harus jelas. Kejelasan undang-undang sangatlah penting. Oleh karena itu setiap undang-undang selalu dilengkapi dengan penjelasan yang dimuat dalam Tambahan Lembaran Negara. Sekalipun nama dan maksudnya sebagai penjelasan, namun sering terjadi penjelasan tersebut, tidak juga memberi kejelasan karena hanya dinyatakan cukup jelas, padahal teks undang-undang tidak jelas dan masih memerlukan penjelasan. Mungkin saja pembentuk undang-undang bermaksud hendak memberi kebebasan yang lebih besar kepada hakim.

Hal yang sama dikemukakan oleh Bagir Manan ${ }^{7}$ :

"Dalam hukum in concreto maupun in abstarcto, ternyata hukum tidak pernah lengkap, tidak pernah sempurna. Secara abstracto tidak pernah ada kemampuan pembentuk hukum (tertulis dan tidak tertulis) yang dapat membuat kaidah yang mencakup seluruh tingkah laku manusia, seluruh kebutuhan individu maupun masyarakat. Sedangkan secara concreto, tidak ada dua peristiwa hukum yang benar-benar serupa, sehingga tidak selalu putusan hakim dapat disandarkan pada bunyi ketentuan yang ada atau mengandalkan putusan terdahulu. Karena hukum disatu pihak tidak pernah lengkap, dipihak lain ada berbagai peristiwa hukum yang harus diselesaikan (secara hukum), maka lahir metode penerapan hukum agar hukum yang tidak lengkap atau tidak jelas, dapat diterapkan secara wajar, tepat dan benar terhadap peristiwa konkrit

7 Bagir manan, Op. cit, hlm. vi 
yang terjadi. Dalam penerapan hukum, dikenal adanya suatu penemuan hukum (rechtsvinding atau legal finding).

Lebih lanjut dikemukakan oleh Bagir Manan ${ }^{8}$, bahwa penemuan hukum diperlukan dalam rangka memecahkan atau menyelesaikan suatu persoalan hukum berdasarkan atau secara hukum. Hukum sebagai dasar yaitu hukum yang berlaku atau hukum positif. Dalam hal hukum positif mengatur suau peristiwa hukum dengan jelas, maka penemuan hukum adalah mempertemukan peristiwa hukum yang konkrit dengan aturan hukum yang ada. Tetapi apabila aturan hukum tidak ada atau tidak jelas, atau simpang siur, penemuan hukum harus diartikan sebagai upaya hakim menemukan pengertian-pengertian hukum yang ada atau menggali berbagai bahan hukum yang bersumber dari berbagai kenyataan, kesadaran atau pandangan hukum atau teori-teori hukum yang tersedia, sehingga suatu peristiwa hukum konkrit dapat dipecahkan dan diselesaikan secara wajar, tepat dan benar.

Demikian pula pendapat Peter Mahmud Marzuki ${ }^{9}$ mengenai apa yang dimaksud dengan penemuan hukum ;

Terlepas dari tidak wajibnya mengikuti preseden, diacunya yurisprudensi kuat bagi penyelesaian sengketa serupa menunjukkan bahwa tugas hakim bukan sekadar menerapkan undang-undang. Melalui putusannya yang menjadi yurisprudensi kuat, hakim juga

8 Ibid, hlm. vii-viii.

9 Peter Mahmud Marzuki, Pengantar Ilmu Hukum, Op. cit., hlm. 282 membuat hukum. Hal itu dalam praktik penyelesaian sengketa tidak dapat dihindari manakala terminologi yang digunakan oleh undang-undang tidak jelas, undang-undang tidak mengatur masalah yang dihadapi atau undang-undang yang ada bertentangan dengan situasi yang dihadapi. Oleh karena itulah hakim dalam hal ini laiu melakukan pembentukan hukum (rechtsvorming), analogi (rechtsanalogie), penghalusan hukum (rechtsverfijning) atau penafsiran (interpretatie). Kegiatankegiatan semacam itu dalam sistem hukum kontinental disebut sebagai penemuan hukum (rechtsvinding).

Dalam melakukan penemuan hukum, dikenal adanya sumber hukum. Menurut Sudikno, ${ }^{10}$ sumber penemuan hukum tidak lain adalah sumber atau tempat terutama bagi hakim untuk dapat menemukan hukumnya. Sumber utama penemuan hukum adalah peraturan perundang-undangan, kemudian hukum kebiasaan, yurisprudensi, perjanjian internasional, barulah doktrin. Oleh karenanya apabila terdapat konflik dua sumber, maka sumber hukum yang tertinggi akan melumpuhkan sumber hukum yang lebih rendah.

Meskipun demikian, menurut Bambang Sutiyoso, ${ }^{11}$ hierarkhi penggunaan sumber-sumber penemuan hukum tidaklah sama dengan hierarkhi norma hukum sebagaimana yang dikemukakan oleh Hans Kelsen. Karena dalam sumber-sumber penemuan

10 Sudikno Mertokusumo, Penemuan Hukum, Op.cit, hlm. 48

11 Bambang Sutiyoso, 2012, Metode Penemuan Hukum, Upaya Mewujudkan Hukum yang Pasti dan Berkeadilan, UII Press, Yogyakarta. hlm. 67. 
hukum tidaklah sumber hukum yang satu lebih tinggi derajatnya daripada yang lain, tetapi prioritas penggunaannyalah yang lebih diutamakan atau didahulukan secara berjenjang mulai dari peraturan perundang-undangan atau hukum tertulis, kemudian hukum kebiasaan dan seterusnya ke bawah. Namun yang harus diingat, meskipun peraturan perundang-undangan atau hukum tertulis sebagai sumber penemuan hukum lebih diutamakan penggunaannya, bukan berarti sumber penemuan hukum yang lain boleh diabaikan begitu saja. Karena pada prinsipnya semua sumber-sumber penemuan hukum saling melengkapi dan bersinergi satu sama lain.

Pembuatan hukum yang

dilakukan secara sengaja oleh badan yang berwenang untuk itu merupakan sumber yang bersifat hukum yang paling utama. Kegiatan dari badan terebut sebagai kegiatan perundang-undangan, yang menghasilkan substansi yang tidak diragukan lagi keabsahannya.

Kelebihan dari peraturan perundang-undangan adalah dalam segi kepastiannya. Kepastian ini dijamin adanya pembuatan hukum yang dilakukan secara sistematik oleh badanbadan yang khusus untuk itu dan teknikteknik perumusannya yang terpelihara dan dikembangkan secara baik.
Menurut Sudikno, ${ }^{12}$ dalam ajaran penemuan hukum, peraturan perundang-undangan diprioritaskan dari sumber-sumber penemuan hukum yang lain. Apabila hendak mencari hukumnya arti suatu kata, maka dicarilah terlebih dahulu dalam peraturan perundangundangan, karena peraturan perundangundangan bersifat otentik dan berbentuk tertulis yang lebih menjamin kepastian hukum.

Tidaklah mudah membaca undang-undang, karena tidak hanya sekedar membaca bunyi kata-kata saja (naarde letter van de wet) tetapi harus pula mencari arti, makna dan tujuannya. Kecuali itu, apa yang di dalam undangundang berlaku sebagai hukum bagi peristiwa konkrit tertentu, tidak secara langsung dapat dilihat dengan mudah dalam undang-undang. Di sini masalahnya bukanlah mengetahui atau hafal isi undang-undangnya, tetapi masalahnya ialah bagaimana menggunakannya. Oleh karena itu membaca undang-undang tidaklah cukup membaca pasal-pasalnya saja, akan tetapi harus pula membaca penjelasan dan konsideran undangundang itu. Bahkan, mengingat bahwa hukum itu adalah suatu sistem, maka untuk memehami suatu pasal dalam Undang-undang atau untuk memahami suatu Undang-undang sering harus dibaca juga pasal-pasal lain dalam satu

12 Sudikno Mertokusumo, Penemuan Hukum, Op. cit, hlm. 48. 
undang-undang itu atau peraturan perundang-undangan yang lain. ${ }^{13}$

Hukum adalah suatu sistem, maka untuk memahami suatu pasal dalam undang-undang atau untuk memahami suatu undang-undang, sering harus dibaca juga pasal-pasal yang lain dalam undang-undang itu atau peraturan perundang-undangan yang lain. Undang-undang tidak boleh diinterpretasikan bertentangan dengan undang-undang itu sendiri (contra legem).

Sumber hukum berikutnya dalam penemuan hukum adalah hukum kebiasaan. Dalam melakukan penemuan hukum, apabila ternyata dalam peraturan perundang-undangan tidak ada ketentuannya atau jawabanya, maka barulah dicari dalam hukum kebiasaan. ${ }^{14}$

Dikatakan oleh Sudikno, ${ }^{15}$ bahwa kebiasaan atau tradisi adalah sumber hukum yang tertua, sumber dari mana dikenal atau digali sebagian dari hukum di luar undang-undang, tempat dapat menemukan atau menggali hukumnya. Kebiasaan merupakan tindakan menurut pola perilaku yang tetap, ajeg, lazim, normal atau adat dalam masyarakat atau pergaulan hidup tertentu. Perilaku yang diulang itu mempunyai kekuatan normatif, mempunyai kekuatan mengikat. Apabila suatu perilaku atau perbuatan itu berlangsung secara ajeg

3 Ibid, hlm. 48.

4 Ibid, hlm. 51

15 Sudikno Mertokusumo, Mengenal Hukum, Op. cit, hlm. 104-105. tetap dan terulang, akan timbullah anggapan bahwa memang demikianlah seharusnya. Meskipun dikatakan bahwa kebiasaan merupakan sumber hukum yang tertua, namun dalam perkembangannya pernah undangundang adalah satu-satunya sumber hukum.

Hukum kebiasaan mempunyai kelemahan-kelemahannya. Hukum kebiasaan bersifat tidak tertulis, oleh karena itu tidak dirumuskan secara jelas dan pada umumnya sukar menggalinya. Disamping itu karena bersifat aneka ragam maka tidak menjamin kepastian hukum dan sering menyulitkan beracara. $^{16}$

Ada dua metode utama yang dipergunakan dalam penemuan hukum yaitu metode penafsiran dan metode konstruksi hukum. Metode penafsiran dipergunakan manakala ada aturannya, namun tidak jelas untuk diterapkan, sedangkan metode konstruksi hukum dipergunakan manakala tidak ada aturannya sama sekali di satu sisi, dan di sisi lain persoalan tersebut harus ditemukan hukumnya.

Dalam metode penafsiran, dikenal beberapa macam penafsiran, diantaranya yaitu penafsiran menurut tata bahasa/gramatika, penafsiran sistematis, penafsiran sejarah dan penafsiran teleologis. Selain bentukbentuk interpretasi sebagaimana dikemukakan di atas, menurut

$16 \quad$ Ibid, hlm. 107. 
Sudikno ${ }^{17}$, dari hasil atau akibat penemuan hukum maka metode interpretasi dapat dibedakan antara interpretasi restriktif dan ekstensif.

Penafsiran berdasarkan tata bahasa atau gramatika adalah penafsiran yang berusaha menemukan arti atau makna kata-kata atau kalimat dalam teks (peraturan perundangundangan) dengan cara menghubungkan arti kata atau kata-kata dengan pengertian atau arti yang lazim dipakai sehari-hari. ${ }^{18}$

Interpretasi gramatikal merupakan interpretasi atau penjelasan undangundang yang paling sederhana dibandingkan dengan metode interpretasi yang lain. ${ }^{19}$

Pada hakekatnya interpretasi undang-undang menurut interpretasi gramatika adalah cara interpretasi permulaan saja. interpretasi gramatika adalah cara yang selalu dipakai pada permulaan usaha interpretasi, yang selanjutnya interpretasi gramatika itu dengan sendirinya membimbing hakim ke arah cara-cara interpretasi yang lain, yaitu interpretasi sistematis.

Menurut Sudikno ${ }^{20}$, karena interpretasi itu merupakan akibat rumusan tertentu dari suatu peraturan, maka dapat menyebabkan dibatasi atau diperluasnya lingkungan penerapan peraturan tersebut. Oleh sebab itulah

\footnotetext{
17 Sudikno Mertokusumo, Penemuan Hukum, Op.cit. hlm. 63.

18 Bagir Manan, Op. cit., hlm. 73

19 Sudikno Mertokusumo, Penemuan Hukum, Op.cit. hlm. 57.

20 Ibid.
}

interpretasi itu dibatasi atau diperluas. Disini bukanlah interpretasinya sendiri yang restriktif atau ekstensif, tetapi pembedaan istilah restriktif dan ekstensif adalah akibat formulasi tertentu dari suatu peraturan yang dibenarkan dengan bantuan interpretasi. Akibat inilah yang dapat membatasi atau memperluas lingkungan penerapan suatu peraturan perundang-undangan.

Interpretasi resktriktif adalah penjelasan atau penafsiran yang bersifat membatasi. Untuk menjelaskan suatu ketentuan undang-undang, ruang lingkup ketentuan itu dibatasi. ${ }^{21}$ Dengan demikian, penafsiran restriktif digunakan untuk membatasi atau memperkecil pengertian suatu ketentuan hukum dengan maksud agar ruang lingkup pengertian suatu ketentuan hukum tidak lagi terlalu luas, sehingga kejelasannya, ketegasannya dan kepastian hukum yang terkandung di dalamnya akan mudah diraih.

Menurut Sudikno, ${ }^{22}$ metodemetode interpretasi itu sering digunakan bersama-sama atau campur aduk, sehingga batasnya tidak dapat ditarik secara tajam. Dapatlah dikatakan bahwa dalam tiap interpretasi terdapat unsur-unsur gramatikal, sistematis, historis dan teleologis.

Berdasarkan keterangan Narasumber Totok Sapto Indrato, S.H., M.H. selaku Ketua Pengadilan Negeri Purbalingga sekaligus Ketua Majelis

\footnotetext{
21 Sudikno Mertokusumo, Mengenal Hukum, Op.cit. hlm. 175.

Ibid., hlm. 64.
} 
dalam tindak pidana perjudian di Pengadilan Negeri Purbalingga. Narasumber menerangkan bahwa sejak diangkat sebagai hakim pada Tahun 1996 sampai dengan saat ini, tidak pernah menyidangkan tindak pidana perjudian secara tertutup untuk umum. Lebih lanjut diterangkan oleh Narasumber :

"Sudah menjadi kebiasaan dalam praktek di Pengadilan bahwa tertutupnya suatu pemeriksaan perkara adalah terhadap perkaraperkara kesusilaan yang berkaitan dengan seks seperti zina, pencabulan, persetubuhan, sedangkan perkara judi melanggar kesusilaan dalam bentuk lain".

Putusan-putusan Narasumber dalam tindak pidana perjudian yang diajukan upaya hukum, juga tidak pernah dibatalkan oleh Pengadilan yang lebih tinggi meskipun pemeriksaannya terbuka untuk umum. Lebih jelas Narasumber menerangkan :

"Putusan Narasumber dalam memeriksa perkara perjudian secara terbuka untuk umum pernah diajukan upaya hukum, namun putusan tersebut tidak dinyatakan batal demi hukum". ${ }^{24}$

Selama ini, Mahkamah Agung tidak pernah mengeluarkan peraturan terhadap sifat persidangan dalam tindak pidana perjudian. Terhadap hal tersebut, narasumber menerangkan :

"Selama ini sepengetahuan Narasumber, tidak ada satu aturan baik itu SEMA maupun PERMA

23 Hasil wawancara dengan Totok Sapto Indrato, S.H.,M.H., Ketua Pengadilan Negeri Purbalingga

24 Hasil wawancara dengan Totok Sapto Indrato, S.H.,M.H., Ketua Pengadilan Negeri Purbalingga yang dikeluarkan oleh Mahkamah Agung mengenai sifat persidangan perkara judi"

Hal yang sama juga disampaikan oleh Narasumber Nenden Rika Puspitasari, S.H., selaku Wakil Ketua Pengadilan Negeri Purbalingga sekaligus Ketua Majelis dalam tindak pidana perjudian di Pengadilan Negeri Purbalingga. Narasumber menerangkan bahwa sejak diangkat sebagai hakim pada tahun 2002 sampai dengan saat ini, tidak pernah menyidangkan tindak pidana perjudian secara tertutup untuk umum. Lebih lanjut Narasumber menerangkan :

"Jika membaca ketentuan pasal 153 ayat (4) KUHAP yang menyebutkan apabila hakim pengadilan dalam memeriksa terdakwa melanggar ketentuan terbuka untuk umum kecuali perkara kesusilaan atau terdakwanya anak-anak, maka putusan hakim tersebut batal demi hukum, namun demikian karena kebiasaan selama ini walaupun perjudian termasuk kesusilaan namun persidangannya dilakukan secara terbuka, sepanjang tidak ada yang mengajukan keberatan tidak berakibat batal demi hukum". ${ }^{25}$

Mengenai ada atau tidaknya peraturan yang dikeluarkan oleh Mahkamah Agung terhadap sifat persidangan dalam tindak pidana perjudian, narasumber menerangkan :

"Sepengetahuan Narasumber, selama ini tidak pernah ada edaran ataupun aturan dari Mahmakah Agung terhadap sifat persidangan perkara perjudian,

25 Hasil wawancara dengan Nenden Rika Puspitasari, S.H., Wakil Ketua Pengadilan Negeri Purbalingga. 
apakah tertutup atau terbuka untuk umum."26

Berdasarkan

pendapat

Narasumber sebagaimana dikemukakan

di atas, maka penerapan asas

pemeriksaan persidangan terbuka untuk umum dalam tindak pidana perjudian merupakan suatu kebiasaan dalam praktek persidangan. Pendapat Narasumber tersebut apabila dikaitkan dengan pendapat Sudikno mengenai kebiasaan sebagai sumber hukum dalam penemuan hukum, maka praktek pengadilan yang menjadi kebiasaan mengenai penerapan asas pemeriksaan persidangan terbuka untuk umum dalam tindak pidana perjudian, hal tersebut diakui dalam penemuan hukum oleh Hakim.

Namun demikian, menurut penulis, terbukanya pemeriksaan persidangan dalam tindak pidana perjudian hanya dengan mendasarkan pada suatu kebisaan, masih belum memberikan argumentasi yang memuaskan. Untuk itu akan dipergunakan metode penafsiran menurut tata bahasa dan penafsiran restriktif.

Kitab Undang-undang Hukum Pidana tidak memberikan definisi pengertian Kesusilaan. Demikian pula Pasal 153 ayat (3) KUHAP berikut penjelasannya. Berdasarkan penelitian Penulis terhadap risalah undang-undang

${ }^{26}$ Hasil wawancara dengan Nenden Rika Puspitasari, S.H., Wakil Ketua Pengadilan Negeri Purbalingga pada tanggal 25 April 2016. nomor 8 Tahun 1981 tentang Hukum Acara Pidana, dalam penjelasan Pasal 153 ayat (3) hanya disebutkan cukup jelas. Selama ini tidak ada suatu peraturan baik perundang-undangan maupun edaran dari Mahkamah Agung yang khusus mengatur tentang terbuka atau tertutupnya pemeriksaan persidangan tindak pidana perjudian.

Hal tersebut juga sesuai dengan keterangan para narasumber bahwa selama ini tidak ada surat edaran ataupun peraturan Mahkamah Agung yang khusus mengatur mengenai terbuka atau tertutupnya persidangan tindak pidana perjudian. Oleh karenanya, untuk dapat memahami pengertian kesusilaan dan tujuan dari terbuka atau tertutupnya suatu pemeriksaan persidangan, akan digunakan yurisprudensi dan pendapat dari para ahli hukum (doktrin).

Sebagaimana dikemukakan oleh Bagir Manan, bahwa sesungguhnya hakim tidak harus terikat oleh suatu yurisprudensi atau putusan-putusan hakim sebelumnya karena Indonesia tidak menganut sistem precedent. Dari beberapa yurisprudensi mengenai pengertian kesusilaan, yang paling sering digunakan adalah Putusan Hoog Rad tanggal 1 desember 1970, NJ Nomor 374, yang menyebutkan bahwa kesusilaan pada umumnya diartikan sebagai rasa kesusilaan yang berkaitan dengan nafsu seksual. Melanggar kesusilaan diartikan sebagai perbuatan yang melanggar rasa malu seksual. 
Namun, apakah pengertian kesusilaan hanya terbatas pada hal-ha yang melanggar rasa malu seksual saja, kiranya perlu dikemukakan beberpa pendapat dari para ahli hukum. Mengenai pengertian delik kesusilaan, Barda Nawawi ${ }^{27}$ menyebutkan :

"Secara singkat dapat dikatakan bahwa delik kesusilaan adalah delik yang berhubungan dengan (masalah) kesusilaan. Definisi singkat dan sederhana itu apabila dikaji lebih lanjut untuk mengetahui seberapa jauh ruang lingkupnya ternyata tidaklah mudah, karena pengertian dan batas-batas "kesusilaan" itu cukup luas dan dapat berbeda-beda menurut pandangan dan nilai-nilai yang berlaku di dalam masyarakat. Terlebih pada dasarnya setiap delik atau tindak pidana mengandung di dalamnya pelanggaran terhadap nilai-nilai kesusilaan;bahkan dikatakan bahwa hukum itu sendiri pada hakikatnya merupakan nilai-nilai kesusilaan yang minimal (das Recht ist das ethische minimum). Membunuh bayi, menelantarkan anak, mencuri, menipu, menggelapkan, membajak hak cipta orang lain, persaingan curang, korupsi dan sebagainya, pada hakikatnya melanggar atau bertentangan dengan nilai-nilai kesusilaan (etika)."

Menurut Barda Nawawi ${ }^{28}$, tidaklah mudah menetapkan batas-batas atau ruang lingkup delik kesusilaan. Dalam lokakarya mengenai "Bab-bab Kodifikasi Hukum Pidana (Buku II)", yang diselenggarakan oleh BPHN Departemen Kehakiman pada tanggal 23-25 April 1985 di Jakarta, masalah ini pernah dilontarkan dalam makalah

27 Barda Nawawi Arief, Op. Cit, hlm. 247.

28 Ibid, hal. 247.
Roeslan Saleh. Dikemukakan dalam makalah tersebut, bahwa pengertian kesusilaan hendaknya tidak dibatasi pada pengertian kesusilaan dalam bidang seksual, tetapi juga meliputi halhal lain yang termasuk dalam penguasaan norma-norma kepatutan bertingkah laku dalam pergaulan masyarakat.

Lebih lanjut dikatakan oleh Barda Nawawi ${ }^{29}$, bahwa walaupun pengelompokan atau ruang lingkup delik kesusilaan bisa berbedabeda, namun patut dicatat pendapat Roeslan Saleh yang menggarisbawahi pandangan Oemar Senoadji, bahwa dalam menentukan isi (materi/substansi)nya harus bersumber dan mendapat sandaran kuat dari moral agama.

Mengenai orientasi delik kesusilaan, Barda Nawawi Arief $^{30}$ mengatakan :

"Saya pun menggarisbawahi pandangan yang demikian walaupun patut ditambahkan, bahwa penentuan delik kesusilaan juga harus berorientasi pada "nilainilai kesusilaan nasional" yang telah disepakati bersama dan juga memperhatikan niai-nilai kesusilaan yang hidup dalam masyarakat. NKN ini dapat digali antara lain dari produk legislative nasional (berbentuk undang-undang dasar atau undang-undang). Dalam struktur masyarakat Indonesia, NKN itu pun tentunya bersumber dari nilai-nilai agama dan kesusilaan yang hidup di tengahtengah masyarakat."

\footnotetext{
29 Ibid, hal. 249.

30 Ibid, hal. 249.
} 
Oemar Seno Adji ${ }^{31}$ memberikan pendapatnya mengenai delik kesusilaan sebagai berikut :

"Kata "delik susila" mengingatkan kita pada delik-delik sexueel, "sexual offences", seperti perzinahan (adulterv), pelacuran (prostitution), homosexualiteit, atau delik-delik yang menurut istilah Prof. Louis B. Scwartz - adalah sex-related, seperti abortus, obscenity dan lain-lain. Kata inilah telah "ingeburgerd", mempunyai nilai sosiologis, karena ia telah diterima oleh kalangan luas dari masyarakat. la tidak menimbulkan persoalan sedikitpun, apakah ia sesuai atau tidak - dengan pengertian dalam Hukum Pidana Positif ataukah ia sesuai atau bertentangan dengan pengertian yang dapat diberikan pada kata "kesusilaan" (zedelijkheid) tersebut. Pandangan masyarakat luaslah dalam hal ini- merupakan faktor determinerend bagi pengertiannya, terlepas dari persoalan apakah yang dikehendaki oleh hukum pidana positif ataupun apa yang dikehendaki oleh kata "kesusilaan" tersebut dalam perundangundangan pidana maupun dalam yursiprudensi pidana kita."

pasal dalam KUHP yang tidak berhubungan dengan seksual di dalam bab XIV tentang kejahatan terhadap kesusilaan, Oemar Seno Adji 32 mengatakan : Hukum pidana positif kita, dalam bab XIV khususnya yang berjudul "tentang kejahatan terhadap kesusilaan" terdapat beberapa ketentuan yang dikatakan oleh Van Bemmelen, menyulitkan pembentuk undang-undang untuk menempatkan beberapa delik di

31 Oemar Seno Adji, Op. Cit, hal. 5-6.

32 Ibid, hal. 6-7 tempat lain. la maksudkan pasal-pasal 300, 301, 302 dan 303 KUHP.

Namun demikian, menurut Van Bemmelen-Van Hattum sebagaimana dikutip P.AF. Lamintang ${ }^{33}$ bahwa ditinjau dari sejarahnya, penempatan tindak pidana yang dimaksud di dalam ketentuan pidana yang diatur dalam pasal 303 KUHP sebagai pidana terhadap kesusilaan itu sudahlah tepat. Tentang hal tersebut Van BemmelenVan Hattum berpendapat bahwa :

"Ditinjau dari sejarahnya sudahlah jelas, bahwa yang merupakan dasar bagi dapat dipidananya perbuatan itu terletak pada kenyataan yakni bahwa oleh permainan tersebut, dan khususnya oleh sifatnya yang khas sebagai "permainan untung-untungan", hasrat orang menjadi tidak dapat dikendalikan dan dapat menimbulkan bahaya bagi penguasaan diri, dan bagi pihak ketiga dapat mempunyai pengaruh, baik yang bersifat menolak maupun yang bersifat menarik. Pengaruh permainan ini dapat meniadakan penilaian yang tidak baik dari orang terhadap perbuatan-perbuatan tidak baik lainnya, yang lebih tidak baik dari permainannya itu sendiri, yakni karena orang selalu melihat adanya hubungan antara perjudian, penyalahgunaan minuman keras dan pelacuran."

Semua bentuk judi tanpa izin adalah kejahatan. Namun, sebelum tahun 1974, judi ada yang berbentuk kejahatan yaitu sebagaimana dimaksud dalam pasal $303 \mathrm{KUHP}$, ada pula yang berbentuk pelanggaran sebagaimana

33 P.A.F. Lamintang, 1990, Delik-Delik Khusus (Tindak-tindak Pidana Melanggar Norma-Norma Kesusilaan dan Norma-Norma Kepatutan), CV Mandar Maju, Bandung, hal. 317. 
dimaksud dalam pasal 542 KUHP. Dengan adanya Undang-undang Nomor 7 Tahun 1974 tentang Penertiban Perjudian, Pasal 542 diubah menjadi pasal 303 bis KUHP. Selain merubah Pasal 542 KUHP menjadi Pasal 303 bis, Undang-undang Nomor 7 Tahun 1974 juga merubah ancaman hukuman dalam tindak pidana judi.

Berdasarkan penjelasan umum atas Undang-undang Nomor 7 tahun 1974 tentang Penertiban Perjudian pada hakekatnya perjudian adalah bertentangan dengan Agama, Kesusilaan, dan Moral Pancasila, serta membahayakan bagi penghidupan dan kehidupan masyarakat, Bangsa, dan Negara. Dari bunyi penjelasan umum Undang-undang Nomor 7 Tahun 1974 tersebut, menurut penulis, Judi dipandang sebagai bentuk kejahatan yang bertentangan dengan kesusilaan, selain juga bertentangan dengan Agama dan moral Pancasila.

Dari beberapa doktrin sebagaimana dikemukakan di atas, maka menurut penulis ada dua pemahaman terhadap makna kesusilaan, yaitu kesusilaan dalam pengertian yang disempitkan yaitu yang berhubungan dengan seksual/sexrelated dan kesusilaan dalam arti luas yang tidak terbatas pada masalah seksual/sex-related. Para Narasumber berpendapat bahwa tindak pidana perjudian termasuk kejahatan kesusilaan dalam arti luas yang tidak terbatas pada masalah seksual/sexrelated. Hanya narasumber Arief
Yudiarto, S.H., M.H. yang memberikan pendapat bahwa tindak pidana perjudian bukan kejahatan seksual dan harus dikeluarkan dari Buku II Bab XIV KUHP. Pendapat narasumber yang menerangkan bahwa tindak pidana perjudian termasuk kejahatan kesusilaan dalam arti luas yang tidak terbatas pada masalah seksual/sexrelated adalah sesuai dengan peraturan perundang-undangan dan pendapat para ahli hukum.

Setelah memahami mengenai makna kesusilaan, selanjutnya akan diuraikan mengenai asas pemeriksaan persidangan terbuka untuk umum. Berkaitan dengan asas pemeriksaan pengadilan adalah terbuka untuk umum, M. Yahya Harap ${ }^{34}$ menyebut asas ini mengandung makna:

"Tindakan penegak hukum harus dilandasi dengan jiwa persamaan dan keterbukaan serta penerapan sistem peradilan pidana musyawarah dan mufakat dari majelis peradilan dalam mengambil keputusan."

Menurut Tolib Effendi ${ }^{35}$, keterbukaan perlakuan oleh aparat penegak hukum kepada tersangka/ terdakwa, tidak dirahasiakan segala sesuatu yang menyangkut pemeriksaan terhadap tersangka / terdakwa. Semua hasil pemeriksaan yang menyangkut diri tersangka / terdakwa tentang kesalahan yang disangkakan kepada tersangka sejak tingkat penyidikan harus

${ }^{44}$ M. Yahya Harahap, 2006, Pembahasan permasalahan Penerapan KUHAP : Penyidikan dan Penuntutan, Sinar Grafika, Jakarta, hal. 56

35 Tolib Effendi, Op.cit, hal. 36. 
disampaikan secara terbuka sampai dengan tingkat pemeriksaan di persidangan.

Secara formil asas pemeriksaan pengadilan terbuka untuk umum, membuka kesempatan "social control" yang bertujuan agar masyarakat bisa mengetahui secara langsung terhadap proses hukum sehingga dapat memberikan kontrol demi terwujudnya keadilan. Pengertian asas terbuka untuk umum ini meliputi proses pemeriksaan Pengadilan hingga putusan hakim. Mengenai hal ini, Fence M. Wantu ${ }^{36}$ berpendapat :

"Pengertian asas ini dapat berarti bahwa siapapun boleh hadir, mendengar dan menyaksikan jalannya pemeriksaan perkara di pengadilan. Asas ini merupakan pengawasan atau kontrol sosial terhadap jalannya peradilan, sekalipun tidak merupakan kontrol langsung terhadap jalannya persidangan, yang akan lebih menjamin objektifitas pemeriksaan yang fair sampai pada putusan yang adil kepada masyarakat. Selain itu asas ini untuk menjamin pelaksanaan peradilan yang tidak memihak dan adil, serta melindungi hak asasi siapapun yang beracara di pengadilan."

Bahwa sidang pemeriksaan pengadilan tertutup untuk umum, dalam perkara kesusilaan seperti zina, persetubuhan dan pencabulan. Hal ini dikarenakan dalam perkara zina, persetubuhan dan pencabulan ada halhal yang tidak pantas diperdengarkan kepada publik. Tertutupnya sidang untuk umum dalam perkara zina,

36 Fence M.Wantu, Op. Cit, hal. 247 persetubuhan dan pencabulan dimaksudkan untuk melindungi dan menjaga psikologi saksi korban. Perlindungan terhadap saksi korban yaitu agar saksi korban dalam memaparkan peristiwa yang dialaminya tanpa harus merasa malu membuka aibnya kembali di depan umum. Saksi korban tidak akan merasa dipermalukan di depan umum karena membuka aib yang menimpanya. Selain itu, dengan terbukanya sidang untuk umum dalam perkara zina, persetubuhan dan pencabulan, dikhawatirkan akan membatasi saksi korban dan terdakwa dalam memberikan keterangan karena adanya perasaan malu, sehingga kebenaran materill yang hendak dicapai dalam pembuktian perkara pidana tidak akan diperoleh.

Terhadap hal tersebut, Wirjono Prodjodikoro ${ }^{37}$ memberikan pendapat:

"Ada kalanya dirasakan perlu untuk melarang khalayak ramai menyaksikan pemeriksaan perkara pidana oleh hakim. Biasanya keperluan ini dirasakan dalam perkara-perkara pidana mengenai hal kesusilaan, misalnya hal memperkosa seorang gadis untuk bersetubuh. Dalam hal ini, kalau khalayak ramai menyaksikan pemeriksaan perkara ada banyak kemungkinan bahwa terdakwa dan saksi-saksi yang bersangkutan sangat malu untuk memajukan keterangan yang sebenarnya, hal mana akan menyulitkan pemeriksaan perkara sedemikian rupa, sehingga hakim tidak dapat mengambil suatu putusan yang tepat."

Hal yang sama disampaikan juga oleh Muhammad Taufik Makaro ${ }^{38}$ bahwa

${ }^{37}$ Wirjono Prodjodikoro, Op. Cit, hlm. 25 
pengecualian terhadap kesusilaan karena kesusilaan dianggap masalahnya sangat pribadi sekali. Tidak patut untuk mengungkapkan dan memaparkannya secara terbuka di muka umum.

Dari pembahasan di atas, menurut penulis, pembuat undangundang tidak memberikan penjelasan yang cukup mengenai batasan tindak pidana kesusilaan yang harus tertutup untuk umum karena pada kenyataannya, tindak pidana kesusilaan tidak hanya terbatas pada yang berhubungan degan seksual saja, sehingga pemeriksaan persidangannya harus dilakukan secara terbuka untuk umum.

Mengenai ketidakjelasan suatu undang-undang, Bagir Manan ${ }^{39}$ telah mengemukakan pendapatnya : Memang karena tugasnya, hakim wajib menemukan penyelesaian, tetapi yang acap kali dilupakan, hakim baik secara hukum maupun sifat wewenang dan tanggungjawabnya dihadapkan pada berbagai batas. Hakim tidak sama sekali bebas seperti pembentuk undangundang. Misalnya dalam menemukan hukum (rechtsvinding), hakim terikat oleh berbagai metode baku yang telah ditentukan, seperti penafsiran, penghalusan hukum dan lain-lain. Itupun

\footnotetext{
${ }^{38}$ Muhammad Taufik Makaro, Op. Cit, hal. 9

${ }^{39}$ Bagir manan, Op. cit, hlm. 48-49)
}

harus mengikuti pengertian baku pemakaian metode tersebut.

Berdasarkan pendapat-pendapat para ahli sebagaimana dikemukakan di atas, maka yang menjadi tujuan dari Asas Persidangan Tertutup Untuk Umum dalam perkara kesusilaan adalah untuk menghindari Terdakwa dan saksisaksi tidak bisa memberikan keterangan yang sebenarnya dengan bebas dikarenakan yang bersangkutan merasa malu terhadap persoalan yang sangat pribadi. Apabila tujuan dari asas persidangan tertutup untuk umum tersebut dikaitkan dengan tindak pidana perjudian sebagai kejahatan kesusilaan dalam arti luas yang tidak terbatas pada masalah seksual / sex-related, maka kekhawatiran terdakwa dan saksi-saksi dalam perkara perjudian tidak bebas dalam memberikan keterangan di persidangan yang terbuka untuk umum, tidak akan terjadi sehingga persidangan dalam perkara perjudian harus dilakukan secara terbuka untuk umum.

Sebagaimana telah dikemukakan pada pembahasan di atas, bahwa ada dua pemahaman terhadap makna kesusilaan, yaitu kesusilaan dalam pengertian yang disempitkan yaitu yang berhubungan dengan seksual/sexrelated dan kesusilaan dalam arti luas yang tidak terbatas pada sex-related. Dengan adanya dua pemahaman terhadap makna kesusilaan tersebut, maka ketentuan pasal 153 ayat (3) KUHAP mengenai pengecualian terbukanya sidang untuk umum dalam perkara kesusilaan, menurut penulis 
memiliki makna yang terlalu luas. Ketentuan tersebut harus dibatasi pengertiannya yaitu hanya terhadap kesusilaan yang berhubungan dengan seksual/sex related. Dengan demikian, menurut Penulis penerapan asas pemeriksaan persidangan terbuka untuk umum dalam perkara perjudian sebagai perkara kesusilaan sesuai dengan Hukum Acara Pidana, sehingga terbukanya pemeriksaan persidangan dalam tindak pidana perjudian, tidak berakibat putusan batal demi hukum.

\section{PENUTUP}

\section{Simpulan}

Berdasarkan hasil penelitian dan pembahasan yang telah dilakukan oleh penulis, maka dapat diambil simpulan, sebagai berikut:

1. Majelis Hakim Pengadilan Negeri Purbalingga menyatakan tindak pidana perjudian sebagai kajahatan kesusilaan, namun menyatakan pemeriksaan persidangannya terbuka untuk umum, dengan pertimbangan yang pertama karena kebiasaan dalam praktek persidangan tindak pidana perjudian selalu terbuka untuk umum. Kedua, tindak pidana perjudian merupakan kejahatan kesusilaan namun dalam arti luas yaitu tidak berhubungan dengan bidang seksual. Ketiga, tidak ada aturan perundang-undangan yang mengatur secara khusus terhadap tata cara pemeriksaan persidangan tindak pidana perjudian sebagai kejahatan kesusilaan harus tertutup untuk umum.

2. Penerapan asas terbuka untuk umum dalam perkara perjudian sebagai perkara kesusilaan sudah seusai dengan hukum acara pidana. Hal tersebut mendasarkan pada alasan yaitu berdasarkan doktrin, ada dua pemahaman terhadap makna kesusilaan, yaitu kesusilaan dalam pengertian yang disempitkan yaitu yang berhubungan dengan seksual / sexrelated dan kesusilaan dalam arti luas yang tidak terbatas pada sexrelated. Judi termasuk dalam perkara kesusilaan dalam arti luas yang tidak terbatas pada sexrelated sehingga persidangannya terbuka untuk umum.

\section{Saran}

$$
\text { Pasal } 153 \text { ayat (3) KUHAP }
$$
sebagai pedoman penerapan asas pemeriksaan persidangan terbuka untuk umum, seharusnya memberikan batasan mengenai kesusilaan, sehingga terhadap perkara kesusilaan yang berhubungan dengan seksual, pemeriksaan persidangannya tertutup untuk umum, sedangkan terhadap perkara kesusilaan yang tidak berhubungan dengan seksual pemeriksaan persidangannya terbuka untuk umum. Oleh karena itu penulis memberikan saran kepada pembuat undang-undang yang saat ini tengah menyusun rancangan undang-undang hukum acara pidana, untuk memberikan 
penjelasan terhadap penerapan Pasal

153 ayat (3) KUHAP.

\section{DAFTAR PUSTAKA}

Arief, Barda Nawawi, 2010, Bunga Rampai Kebijakan Hukum Pidana (perkembangan penyusunan konsep KUHP baru), Kencana Prenada Media Group, Jakarta.

Effendi, Tolib, 2014, Dasar-Dasar Hukum Acara Pidana: Perkembangan dan pembaharuannya di Indonesia, Setara Press, Malang.

Fajar, Mukti dan Yulianto Achmad, 2010, Dualisme Penelitian Hukum Normatif dan Empiris, Pustaka Pelajar, Yogyakarta.

Harahap, M. Yahya, 2006, Pembahasan Permasalahan dan Penerapan KUHAP : Penyidikan dan Penuntutan, Sinar Grafika, Jakarta.

Lamintang, P.A.F., 1990, Delik-Delik Khusus (Tindak-tindak Pidana Melanggar Norma-Norma Kesusilaan dan Norma-Norma Kepatutan), CV Mandar Maju, Bandung.

Mahmud Marzuki, Peter, 2011, Pengantar IImu Hukum, Kencana Prenada Media, Jakarta.

Manan, Bagir, 2004, Hukum Positif Indonesia (suatu kajian teoritik), FH UII Press, Yogyakarta.

Mertokusumo, Sudikno, 2006, Penemuan Hukum suatu Pengantar, Liberty, Yogyakarta.

Mertokusumo, Sudikno, 2008, Mengenal Hukum, Liberty, Yogyakarta.

M. Wantu, Fence, 2011, Kepastian Hukum, Keadilan dan Kemanfaatan, Pustaka Pelajar, Yogyakarta.

Prodjodikoro, Wirjono 1981, Hukum Acara Pidana di Indonesia, Sumur Bandung, Bandung.

Soejono dan H. Abdurahman, 2003, Metode Penelitian Hukum, Rineka Cipta, Jakarta.

Sutiyoso, Bambang, 2012, Metode Penemuan Hukum, Upaya Mewujudkan Hukum yang Pasti dan Berkeadilan, UII Press, Yogyakarta.
Taufik Makaro, Muhammad dan Suhasril, 2004, Hukum Acara Pidana Dalam Teori dan Praktek, Ghalia Indonesia, Jakarta.

Kamil, Iskandar, 2003, Kode Etik Profesi Hakim, dalam Pedoman Perilaku Hakim (Code of Conduct) Kode Etik Hakim dan Makalah Berkaitan, Mahkamah Agung RI, Jakarta. 